\title{
Putusan Mahkamah Konstitusi Dan Implikasinya Terhadap Pencari Keadilan
}

\author{
Bambang Sutiyoso \\ FH UII Jl. Taman Siswa No. 158 Yogyakarta \\ e-mail : bambang@fh.uii.ac.id / abangyos@yahoo.co.uk.
}

\begin{abstract}
The verdict of the Constitutional Court, as the nature of a court decision, implies the rights that the justice seekers enjoy. It is unfortunate however, the appeal procedure for those who are not satisfied with such verdict is not issued yet, and this may produce the disadvantages for the purpose of affording justice. For such reason, the amendment on the Constitutional Court procedures, particularly in appeal procedures, is highly demanded.
\end{abstract}

Keywords: Verdict, Constitutional Court, Legal Consequence, Justice Seeker

\section{Pendahuluan}

Lahirnya Mahkamah Konstitusi menandai era baru dalam sistem kekuasaan kehakiman di Indonesia. Beberapa wilayah yang tadinya tidak tersentuh (untouchable) oleh hukum, seperti masalah judicial review terhadap undang-undang, sekarang dapat dilakukan oleh Mahkamah Konstitusi. Di samping itu juga kewenangan-kewenangan lainnya yang diatur dalam UUD 1945 pasca Amandemen. Munculnya Mahkamah Konstitusi sebagai pelaku kekuasaan kehakiman diharapkan menjadi entry point yang mendorong terwujudnya sistem kekuasaan kehakiman yang modern di Indonesia.

Meskipun demikian, sebagai institusi peradilan yang baru, masih banyak persoalan yang memerlukan pengkajian lebih jauh, khususnya berkaitan dengan ketentuan hukum acaranya yang ada beberapa perbedaan dengan ketentuan hukum acara pada umumnya. Di sisi lain, secara umum tidak dapat dipungkiri bahwa sebagian masyarakat khususnya pencari keadilan (justiciabellen), belum sepenuhnya memahami aturan main (rule of game) dan tata cara prosedur pemeriksaannya, 
termasuk mengenai persoalan putusan Mahkamah Konstitusi dan bagaimana implikasinya terhadap pencari keadilan.

Salah satu issue yang menjadi perbincangan publik selama ini adalah kontroversi mengenai tidak dimungkinkannya pihak-pihak yang berperkara mengajukan upaya hukum terhadap putusan Mahkamah Konstitusi. Secara normatif, Hukum Acara Mahkamah Konstitusi sebagaimana diatur dalam UU No. 24 tahun 2003 Tentang Mahkamah Konstitusi tidak mengakomodir adanya upaya hukum terhadap putusan Mahkamah Konstitusi yang telah dijatuhkan. Putusan Mahkamah Konstitusi bersifat final dan mengikat, yaitu sebagai putusan tingkat pertama sekaligus pula sebagai putusan tingkat terakhir. Sehingga pencari keadilan tidak memiliki alternatif lain, mau tidak mau, suka maupun tidak suka harus menerima putusan yang dijatuhkan.

Dalam konteks itulah, tulisan ini berupaya memaparkan beberapa persoalan menyangkut putusan Mahkamah Konstitusi dan implikasinya terhadap pencari keadilan (justiciabellen). Secara garis besar persoalan yang muncul adalah pengaturan mengenai Putusan Mahkamah Konstitusi, isi dan karakteristik putusan, rekapitulasi putusan Mahkamah Konstitusi terakhir, beberapa putusan Mahkamah Konstitusi yang penting, serta tentang finalnya putusan Mahkamah Konstitusi sehingga upaya hukum terhadap putusan tidak dikenal. Deskripsi tulisan ini diharapkan dapat lebih memperjelas fenomena seputar persoalan putusan Mahkamah Konstitusi dan problematikanya yang sering dipersoalkan dalam praktik selama ini.

\section{Putusan Mahkamah Konstitusi}

Salah satu tugas Hakim Mahkamah Konstitusi adalah mengkonstituir atau memutuskan perkara yang diajukan oleh pihak-pihak yang berperkara. Hakim terlebih dahulu harus mengkonstatir peristiwanya, kemudian dilanjutkan dengan mengkualifisir peristiwa hukumnya, sebelum pada akhirnya harus mengkonstituir atau memutuskan perkaranya.

Pada dasarnya putusan hakim adalah suatu pernyataan yang dibuat oleh hakim, sebagai pejabat negara yang diberi wewenang untuk itu, diucapkan dalam persidangan dan bertujuan untuk mengakhiri atau menyelesaiakan suatu perkara atau sengketa antara para pihak. ${ }^{1}$ Putusan

${ }^{1}$ Sudikno Mertokusumo, Hukum Acara Perdata Indonesia, Liberty, Yogyakarta, hlm. 175. 
hakim ini diharapkan dapat memberikan kepastian hukum dan keadilan kepada pihak-pihak yang berperkara.

Ketentuan yang berkaitan dengan Putusan Mahkamah Konstitusi diatur dalam Pasal 45 sampai dengan 49 UU Mahkamah Konstitusi. Dalam Pasal 45 disebutkan sebagai berikut : (1) Mahkamah Konstitusi memutus perkara berdasarkan Undang-Undang Dasar Negara Republik Indonesia Tahun 1945 sesuai dengan alat bukti dan keyakinan hakim; (2) putusan Mahkamah Konstitusi yang mengabulkan permohonan harus didasarkan pada sekurangkurangnya 2 (dua) alat bukti; (3) putusan Mahkamah Konstitusi wajib memuat fakta yang terungkap dalam persidangan dan pertimbangan hukum yang menjadi dasar putusan; (4) putusan sebagaimana dimaksud pada ayat (3) diambil secara musyawarah untuk mufakat dalam sidang pleno hakim konstitusi yang dipimpin oleh ketua sidang; (5) dalam sidang permusyawaratan, setiap hakim konstitusi wajib menyampaikan pertimbangan atau pendapat tertulis terhadap permohonan;(6) dalam hal musyawarah sidang pleno hakim konstitusi sebagaimana dimaksud pada ayat (4) tidak dapat menghasilkan putusan, musyawarah ditunda sampai musyawarah sidang pleno hakim konstitusi berikutnya; (7) dalam hal musyawarah sidang pleno setelah diusahakan dengan sungguh-sungguh tidak dapat dicapai mufakat bulat, putusan diambil dengan suara terbanyak; (8) dalam hal musyawarah sidang pleno hakim konstitusi sebagaimana dimaksud pada ayat (7) tidak dapat diambil dengan suara terbanyak, suara terakhir ketua sidang pleno hakim konstitusi menentukan; (9) putusan Mahkamah Konstitusi dapat dijatuhkan pada hari itu juga atau ditunda pada hari lain yang harus diberitahukan kepada para pihak; (10) dalam hal putusan tidak tercapai mufakat bulat sebagaimana dimaksud pada ayat (7) dan ayat (8), pendapat anggota Majelis Hakim yang berbeda dimuat dalam putusan.

Ketentuan Pasal 45 di atas, menyebutkan tentang dasar, prosedur atau mekanisme dan tata cara pengambilan putusan secara musyawarah untuk mufakat di lingkungan majelis hakim konstitusi.

Dasar yang dipergunakan oleh Mahkamah Konstitusi dalam memutus perkara adalah Undang-Undang Dasar Negara Republik Indonesia Tahun 1945 sesuai dengan alat bukti dan keyakinan hakim. Sebagai organ konstitusi, lembaga ini didesain untuk menjadi pengawal dan sekaligus penafsir terhadap Undang-Undang Dasar melalui putusan-putusannya.

Alat bukti dan keyakinan hakim merupakan syarat komulatif yang harus dipenuhi untuk sahnya atau terbuktinya suatu peristiwa dalam pembuktian. Dalam menjatuhkan putusan yang berisi mengabulkan 
permohonan, Mahkamah Konstitusi yang harus mendasarkan pada sekurang-kurangnya 2 (dua) alat bukti. Sedangkan yang dimaksud dengan "keyakinan Hakim" adalah keyakinan hakim berdasarkan alat bukti. Keyakinan hakim tidak boleh muncul secara tiba-tiba, tetapi harus berdasarkan pada alat bukti. ${ }^{2}$

Sebagaimana dalam putusan hakim lainnya, putusan Mahkamah Konstitusi juga wajib memuat fakta yang terungkap dalam persidangan dan pertimbangan hukum yang menjadi dasar putusan. Fakta yang terungkap dan pertimbangan hukum dari putusan tidak lain adalah alasan-alasan hakim sebagai pertanggung jawaban mengapa ia sampai mengambil putusan demikian, sehingga putusan tersebut mempunyai nilai objektif. Adanya alasan dalam pertimbangan hukum dari suatu putusan menyebabkan putusan mempunyai nilai objektif, kecuali itu juga wibawa. ${ }^{3}$

Putusan hakim konstitusi harus diambil secara musyawarah untuk mufakat dalam sidang pleno hakim konstitusi yang dipimpin oleh ketua sidang. Dalam sidang permusyawaratan, setiap hakim konstitusi wajib menyampaikan pertimbangan atau pendapat tertulis terhadap permohonan. Berdasarkan ketentuan ini dalam sidang permusyawaratan pengambilan putusan tidak ada suara hakim yang abstain. Dalam hal musyawarah sidang pleno hakim konstitusi tidak dapat menghasilkan putusan, musyawarah ditunda sampai musyawarah sidang pleno hakim konstitusi berikutnya.

Dalam hal musyawarah sidang pleno setelah diusahakan dengan sungguh-sungguh tidak dapat dicapai mufakat bulat, putusan diambil dengan suara terbanyak. Dalam hal musyawarah sidang pleno hakim konstitusi tidak dapat diambil dengan suara terbanyak, suara terakhir ketua sidang pleno hakim konstitusi menentukan.

Dalam putusan Mahkamah Konstitusi dikenal lembaga dissenting opinion, yaitu dalam hal putusan tidak tercapai mufakat bulat, pendapat anggota Majelis Hakim yang berbeda dimuat dalam putusan. Putusan Mahkamah Konstitusi dapat dijatuhkan pada hari itu juga atau ditunda pada hari lain yang harus diberitahukan kepada para pihak berdasarkan alasan-alasan yang objektif.

Dalam putusan Mahkamah Konstitusi diberlakukan dissenting opinion, yaitu menyertakan pendapat hakim konstitusi yang berbeda, apabila

\footnotetext{
${ }^{2}$ Bambang Sutiyoso, Hukum Acara Mahkamah Konstitusi Republik Indonesia, Citra Aditya Bakti, Bandung, 2006, hlm. 120.

${ }^{3}$ Sudikno Mertokusumo, Op.Cit., hlm. 186.
} 
proses pengambilan putusan oleh Mahkamah Konstitusi dilakukan dengan suara terbanyak. Penyertaan pendapat Hakim Konstitusi yang berbeda ini perlu disertakan, agar masyarakat dapat mengetahui alasan masingmasing hakim konstitusi, dan menilai tingkat integritas serta kualitas seorang hakim konstitusi dalam memutus suatu perkara. Dissenting opinion dikecualikan dalam perkara impeachment, karena perkara tersebut memiliki dimensi-dimensi politis, yang dapat mempengaruhi secara psikologis bagi para hakim konstitusi dalam berpendapat dan mengambil putusan. ${ }^{4}$

Putusan Mahkamah Konstitusi ditandatangani oleh hakim yang memeriksa, mengadili, dan memutus, dan panitera. Putusan Mahkamah Konstitusi memperoleh kekuatan hukum tetap sejak selesai diucapkan dalam sidang pleno terbuka untuk umum. Dengan demikian putusan hakim konstitusi bersifat final dan tidak memungkinkan diajukannya upaya hukum lebih lanjut. ${ }^{5}$

\section{Isi Putusan Mahkamah Konstitusi}

Berdasarkan ketentuan dalam Pasal 56, pada dasarnya isi putusan hakim konstitusi dapat berupa 3 macam, yaitu: permohonan tidak diterima, permohonan ditolak, serta permohonan dikabulkan. Sedangkan putusan gugur maupun putusan verstek tidak dikenal dalam hukum acara Mahkamah Konstitusi. Meskipun pemohon atau termohon tidak hadir dalam persidangan, pemeriksaan perkara tetap dilanjutkan. Ketidakhadiran pemohon dan termohon dalam persidangan akan merugikan kepentingannya sendiri, karena tidak menggunakan kesempatannya untuk memberikan pembelaan perkaranya dalam persidangan. ${ }^{6}$

\section{Permohonan Tidak Diterima (niet onvankelijk verklaard).}

Putusan hakim konstitusi menyatakan permohonan tidak dapat diterima (niet onvankelijk verklaard), apabila permohonannya melawan hukum atau tidak berdasarkan hukum. Dalam hal ini Mahkamah Konstitusi berpendapat bahwa pemohon dan/atau permohonannya tidak memenuhi syarat sebagaimana dimaksud dalam Pasal 50 dan Pasal 51, maka amar putusan menyatakan permohonan tidak dapat diterima.

${ }^{4}$ A. Fickar Hadjar, dkk, Pokok-Pokok Pikiran dan Rancangan Undang-Undang Mahkamah Konstitusi, KRHN dan Kemitraan, 2003, hlm. 51.

${ }^{5}$ Bambang Sutiyoso, Op. Cit., hlm. 122.

${ }^{6}$ Ibid. 
Pasal 50 menyebutkan, bahwa undang-undang yang dapat dimohonkan untuk diuji adalah undang-undang yang diundangkan setelah perubahan Undang-Undang Dasar Negara Republik Indonesia Tahun 1945. Sedangkan Pasal 51 menyatakan sebagai berikut : (1) pemohon adalah pihak yang menganggap hak dan/atau kewenangan konstitusionalnya dirugikan oleh berlakunya undang-undang, yaitu: a. perorangan warga negara Indonesia; $b$. kesatuan masyarakat hukum adat sepanjang masih hidup dan sesuai dengan perkembangan masyarakat dan prinsip Negara Kesatuan Republik Indonesia yang diatur dalam undang-undang; c. badan hukum publik atau privat; atau d. lembaga negara.; (2) pemohon wajib menguraikan dengan jelas dalam permohonannya tentang hak dan/atau kewenangan konstitusionalnya sebagaimana dimaksud pada ayat (1); (3) dalam permohonan sebagaimana dimaksud pada ayat (2), pemohon wajib menguraikan dengan jelas bahwa: a. pembentukan undang-undang tidak memenuhi ketentuan berdasarkan Undang-Undang Dasar Negara Republik Indonesia Tahun 1945; dan/ atau b. materi muatan dalam ayat, pasal, dan/atau bagian undangundang dianggap bertentangan dengan Undang-Undang Dasar Negara Republik Indonesia Tahun 1945.

Mahkamah Konstitusi di sini dapat bertindak sebagai negative legislator, yaitu boleh jadi mengabulkan permohonan pemohon atau menolaknya. Tetapi juga ada kemungkinan bahwa permohonan dinyatakan tidak diterima karena tidak memenuhi syarat formal yang diharuskan. Putusan Mahkamah Konstitusi dapat meniadakan satu keadaan hukum atau menciptakan hak atau kewenangan tertentu. Dengan kata lain, putusan itu akan membawa akibat tertentu yang mempengaruhi satu keadaan hukum atau hak dan atau kewenangan. ${ }^{7}$

\section{Permohonan ditolak (ontzegd)}

Putusan hakim konstitusi menyatakan permohonan ditolak, apabila permohonannya tidak beralasan. Dalam hal ini undang-undang dimaksud tidak bertentangan dengan Undang-Undang Dasar Negara Republik Indonesia Tahun 1945, baik mengenai pembentukan maupun materinya sebagian atau keseluruhan, maka amar putusannya menyatakan permohonan ditolak.

${ }^{7}$ Maruarar Siahaan, Hukum Acara Mahkamah Konstitusi Republik Indonesia, Konstitusi Press, Jakarta, 2005, hlm. 213. 
Putusan Mahkamah Konstitusi yang amar putusannya menyatakan bahwa materi muatan ayat, pasal, dan/atau bagian undang-undang bertentangan dengan Undang-Undang Dasar Negara Republik Indonesia Tahun 1945, materi muatan ayat, pasal, dan/atau bagian undang-undang tersebut tidak mempunyai kekuatan hukum mengikat. Demikian pula putusan Mahkamah Konstitusi yang amar putusannya menyatakan bahwa pembentukan undang-undang dimaksud tidak memenuhi ketentuan pembentukan undang-undang berdasarkan Undang-Undang Dasar Negara Republik Indonesia Tahun 1945, undang-undang tersebut tidak mempunyai kekuatan hukum mengikat.

\section{Permohonan dikabulkan}

Putusan menyatakan permohonan dikabulkan, yaitu apabila permohonannya beralasan, dalam hal ini Mahkamah Konstitusi berpendapat bahwa permohonan beralasan atau dalam hal pembentukan undang-undang dimaksud tidak memenuhi ketentuan pembentukan undang-undang berdasarkan Undang-Undang Dasar Negara Republik Indonesia Tahun 1945, amar putusan menyatakan permohonan dikabulkan. Dalam hal permohonan dikabulkan, Mahkamah Konstitusi menyatakan dengan tegas materi muatan ayat, pasal, dan/atau bagian dari undang-undang yang bertentangan dengan Undang-Undang Dasar Negara Republik Indonesia Tahun 1945.

Putusan Mahkamah Konstitusi yang mengabulkan permohonan wajib dimuat dalam Berita Negara dalam jangka waktu paling lambat 30 (tiga puluh) hari kerja sejak putusan diucapkan. Terhadap materi muatan ayat, pasal, dan/atau bagian dalam undang-undang yang telah diuji, tidak dapat dimohonkan pengujian kembali dikemudian hari (nebis in idem). Putusan Mahkamah Konstitusi mengenai pengujian undang-undang terhadap Undang-Undang Dasar Negara Republik Indonesia Tahun 1945 disampaikan kepada DPR, Dewan Perwakilan Daerah, Presiden, dan Mahkamah Agung.

Di samping macam-macam isi putusan sebagaimana diuraikan di atas, untuk memberikan gambaran putusan yang lebih jelas, maka berikut ini akan diuraikan lebih lanjut putusan dari masing-masing perkara yang menjadi kewenangan Mahkamah Konstitusi, karena masing-masing mempunyai karakteristik khusus yang membedakan satu sama lain. 


\section{Putusan dalam Perkara Pengujian Undang-Undang}

Perkara mengenai pengujian Undang-Undang terhadap UndangUndang Dasar diatur secara khusus dalam Pasal 50 sampai 60 UU Mahkamah Konstitusi. Berdasarkan ketentuan Pasal 50, Undang-undang yang dapat dimohonkan untuk diuji adalah undang-undang yang diundangkan setelah perubahan Undang-Undang Dasar Negara Republik Indonesia Tahun 1945. Perlu diingat, Pasal 50 tersebut sudah dinyatakan tidak mengikat oleh Mahkamah Konstitusi dalam putusannya. Meskipun demikian, selama undang-undang tersebut diuji oleh Mahkamah Konstitusi masih tetap berlaku, sebelum ada putusan yang menyatakan bahwa undang-undang tersebut bertentangan dengan Undang-Undang Dasar Negara Republik Indonesia Tahun 1945.

Selanjutnya dalam pasal 51 ayat (1) UU Mahkamah konstitusi disebutkan bahwa :"Pemohon adalah pihak yang menganggap hak dan/ atau kewenangan konstitusionalnya dirugikan oleh berlakunya UndangUndang". Selanjutnya dalam pasal itu diatur mengenai kedudukan hukum (legal standing) dari Pemohon, yaitu : a) perorangan warga negara; b) kesatuan masyarakat hukum adapt sepanjang masih hidup dan sesuai dengan perkembangan masyarakat dan prinsip Negara Kesatuan RI; c) badan hukum publik atau privat; d) lembaga negara.

Apabila dicermati, ketentuan yang terdapat dalam pasal di atas sebenarnya mengandung ketidakjelasan yang berakibat pada sulitnya para Hakim Konstitusi membuktikan dan mengaitkan pelanggaran yang didalilkan oleh pemohon terhadap serangkaian ketentuan yang terdapat dalam UUD 1945. Pasal 51 ayat (1) butir d UU Mahkamah konstitusi yang memberi legal standing kepada lembaga-lembaga negara, seharusnya ditentukan lebih jelas, lembaga-lembaga apa saja yang dapat digolongkan sebagai lembaga negara. Sebab ada beberapa lembaga negara seperti DPR, DPD, MPR, Presiden dan Wakil Presiden, MA, BPK, Komisi Yudisial, KPU, TNI/Polri dan Lembaga Negara tingkat daerah lainnya. ${ }^{8}$

\section{Putusan dalam Sengketa Kewenangan Lembaga Negara}

Berdasarkan pasal 24C ayat (1) UUD 1945, salah satu kewenangan dari Mahkamah Konstitusi adalah memutus sengketa kewenangan antara

${ }^{8}$ Bandingkan dengan tulisan Ahmad Syahrizal, Peradilan Konstitusi Suatu Studi Tentang Adjudikasi Konstitusional Sebagai Mekanisme Penyelesaian Sengketa Normatif, Pradnya Paramita, Jakarta, 2006, hlm. 312. 
lembaga Negara yang kewenangannya diberi oleh Undang-Undang Dasar. Konsepsi tentang lembaga negara yang kewenangannya diberikan oleh UUD, mengandung interpretasi yang beragam. Hal ini disebabkan pasca amandemen, konstitusi tidak memberikan kejelasan konsepsi tentang lembaga negara. Sedangkan UU Mahkamah Konstitusi sendiri ternyata juga tidak memberikan kejelasan konsepsi tentang lembaga negara. ${ }^{9}$

Perkara tentang sengketa kewenangan Lembaga negara yang kewenangannya diberikan oleh Undang-Undang Dasar diatur lebih lanjut dalam ketentuan Pasal 61 sampai 67 UU Mahkamah Konstitusi. Sebagai pengecualian dalam hal ini diatur dalam Pasal 65, yang menyatakan bahwa Mahkamah Agung tidak dapat menjadi pihak dalam sengketa kewenangan lembaga negara yang kewenangannya diberikan oleh Undang-Undang Dasar Negara Republik Indonesia Tahun 1945 pada Mahkamah Konstitusi.

Setelah dilakukan proses pemeriksaan, Mahkamah Konstitusi dapat menjatuhkan beberapa kemungkinan bunyi amar putusan, yaitu menyatakan permohonan tidak dapat diterima, permohonan dikabulkan atau menyatakan permohonan ditolak. Amar putusan menyatakan permohonan tidak dapat diterima, dalam hal Mahkamah Konstitusi berpendapat bahwa pemohon dan/atau permohonannya tidak memenuhi syarat sebagaimana dimaksud dalam Pasal 61. Amar putusan menyatakan permohonan dikabulkan, dalam hal Mahkamah Konstitusi berpendapat bahwa permohonan beralasan. Dalam hal permohonan dikabulkan, Mahkamah Konstitusi menyatakan dengan tegas bahwa termohon tidak mempunyai kewenangan untuk melaksanakan kewenangan yang dipersengketakan. Selanjutnya amar putusan menyatakan permohonan ditolak, dalam hal permohonan tidak beralasan.

Putusan Mahkamah Konstitusi yang amar putusannya menyatakan bahwa termohon tidak mempunyai kewenangan untuk melaksanakan kewenangan yang dipersengketakan, termohon wajib melaksanakan putusan tersebut dalam jangka waktu paling lambat 7 (tujuh) hari kerja sejak putusan diterima. Jika putusan tersebut tidak dilaksanakan dalam jangka waktu sebagaimana dimaksud pada ayat (1), pelaksanaan kewenangan termohon batal demi hukum. Selanjutnya putusan Mahkamah Konstitusi mengenai sengketa kewenangan disampaikan kepada DPR, Dewan Perwakilan Daerah, dan Presiden.

${ }^{9}$ Fatkhurohman, dkk, Memahami Keberadaan Mahkamah Konstitusi Di Indonesia, Citra Aditya Bakti, Bandung, 2004, hlm. 35. 


\section{Putusan tentang Pembubaran Partai Politik}

Masalah pembubaran partai politik diatur dalam Pasal 68 sampai 73 UU Mahkamah Konstitusi. Sebagaimana dalam perkara yang lain, dalam permohonan atas pembubaran partai politik ada tiga kemungkinan amar putusan yang akan dijatuhkan oleh Mahkamah Konstitusi, yaitu permohonan dinyatakan tidak diterima, permohonan dikabulkan atau permohonan dinyatakan ditolak. Permohonan dinyatakan tidak diterima, apabila Mahkamah Konstitusi berpendapat bahwa permohonan tidak memenuhi syarat sebagaimana dimaksud dalam Pasal 68. Amar putusan menyatakan permohonan dikabulkan, apabila Mahkamah Konstitusi berpendapat bahwa permohonan tersebut beralasan. Sedangkan putusan menyatakan permohonan ditolak, dalam hal Mahkamah Konstitusi berpendapat bahwa permohonan tidak beralasan.

Putusan Mahkamah Konstitusi mengenai permohonan atas pembubaran partai politik wajib diputus dalam jangka waktu paling lambat 60 (enam puluh) hari kerja sejak permohonan dicatat dalam Buku Registrasi Perkara Konstitusi. Selanjutnya putusan Mahkamah Konstitusi mengenai pembubaran partai politik disampaikan kepada partai politik yang bersangkutan.

Putusan Mahkamah Konstitusi dalam hal pembubaran Partai politik, belum tegas ditentukan bagaimana bunyi amarnya apakah menyatakan bubar atau setelah menerima putusan, memerintahkan partai politik yang bersangkutan bubar atau membubarkan diri. Tetapi eksekusi putusan pembubaran partai politik dilakukan dengan membatalkan pendaftaran pada Pemerintah (Departemen Hukum dan HAM), serta mengumumkan dalam Berita Negara dalam jangka waktu 14 (emapat belas) hari sejak putusan diterima. ${ }^{10}$

\section{Putusan tentang Perselisihan Hasil Pemilu}

Perkara tentang tentang perselisihan hasil Pemilu diatur lebih lanjut dalam Pasal 74 sampai 79 UU Mahkamah Konstitusi.

Beberapa kemungkinan isi putusan yang akan dijatuhkan oleh Mahkamah Konstitusi dalam perkara perselisihan hasil Pemilu adalah permohonan dinyatakan tidak diterima, permohonan dikabulkan atau permohonan dinyatakan ditolak. Putusan menyatakan permohonan tidak

${ }^{10}$ Agung Susanto, Hukum Acara Perkara Konstitusi, Mandar Maju, Bandung, 2006, hlm. 51 . 
dapat diterima, apabila Mahkamah Konstitusi berpendapat bahwa pemohon dan/atau permohonannya tidak memenuhi syarat sebagaimana dimaksud dalam Pasal 74. Sedangkan dalam hal Mahkamah Konstitusi berpendapat bahwa permohonan beralasan, amar putusan menyatakan permohonan dikabulkan. Dalam hal permohonan dikabulkan, Mahkamah Konstitusi selanjutnya menyatakan membatalkan hasil penghitungan suara yang diumumkan oleh Komisi Pemilihan Umum dan menetapkan hasil penghitungan suara yang benar. Putusan Mahkamah Konstitusi menyatakan permohonan ditolak, apabila permohonan yang diajukan tidak beralasan.

Mengenai jangka waktu putusan Mahkamah Konstitusi mengenai permohonan atas perselisihan hasil pemilihan umum ditentukan dalam Pasal 78. Pasal 78 menyatakan bahwa putusan Mahkamah Konstitusi mengenai permohonan atas perselisihan hasil pemilihan umum wajib diputus dalam jangka waktu: (a) paling lambat 14 (empat belas) hari kerja sejak permohonan dicatat dalam Buku Registrasi Perkara Konstitusi, dalam hal pemilihan umum Presiden dan Wakil Presiden; (b) paling lambat 30 (tiga puluh) hari kerja sejak permohonan dicatat dalam Buku Registrasi Perkara Konstitusi, dalam hal pemilihan umum anggota DPR, Dewan Perwakilan Daerah, dan Dewan Perwakilan Rakyat Daerah.

Putusan Mahkamah Konstitusi mengenai perselisihan hasil pemilihan umum selanjutnya disampaikan kepada Presiden.

\section{Putusan Mengenai Dugaan Pelanggaran oleh Presiden dan atau Wakil Presiden}

Perkara tentang Pendapat DPR mengenai Dugaan Pelanggaran oleh Presiden dan /atau wakil Presiden diatur dalam Pasal 80 sampai 85 UU Mahkamah Konstitusi. Dalam perkara ini yang bertindak sebagai pihak pemohon adalah Dewan Perwakilan Rakyat (DPR).

Dalam Pasal 83 dijelaskan tentang putusan yang dapat dijatuhkan oleh Mahkamah Konstitusi dalam perkara ini ada tiga (3) kemungkinan, yaitu permohonan dinyatakan tidak dapat diterima (niet onvankelijk verklaard), putusan membenarkan pendapat DPR; serta putusan menyatakan permohonan ditolak. Putusan menyatakan permohonan tidak dapat diterima, apabila Mahkamah Konstitusi berpendapat bahwa permohonan tidak memenuhi syarat sebagaimana dimaksud dalam Pasal 80. Putusan menyatakan membenarkan pendapat DPR, apabila Mahkamah Konstitusi memutuskan bahwa Presiden dan/atau Wakil Presiden terbukti melakukan pelanggaran hukum berupa pengkhianatan 
terhadap negara, korupsi, penyuapan, tindak pidana berat lainnya, atau perbuatan tercela dan/atau terbukti bahwa Presiden dan/atau Wakil Presiden tidak lagi memenuhi syarat sebagai Presiden dan/atau Wakil Presiden. Selanjutnya putusan menyatakan permohonan ditolak, apabila Mahkamah Konstitusi memutuskan bahwa Presiden dan/atau Wakil Presiden tidak terbukti melakukan pelanggaran hukum berupa pengkhianatan terhadap negara, korupsi, penyuapan, tindak pidana berat lainnya, atau perbuatan tercela dan/atau tidak terbukti bahwa Presiden dan/atau Wakil Presiden tidak lagi memenuhi syarat sebagai Presiden dan/atau Wakil Presiden.

Putusan Mahkamah Konstitusi mengenai permohonan atas pendapat DPR mengenai dugaan pelanggaran sebagaimana dimaksud dalam Pasal 80, wajib diputus dalam jangka waktu paling lambat 90 (sembilan puluh) hari sejak permohonan dicatat dalam Buku Registrasi Perkara Konstitusi. Putusan Mahkamah Konstitusi mengenai pendapat DPR wajib disampaikan kepada DPR dan Presiden dan/atau Wakil Presiden.

\section{Rekapitulasi Putusan Mahkamah Konstitusi Terakhir}

Sesuai dengan kewenangannya, perkara yang sudah ditangani Mahkamah Konstitusi adalah perkara permohonan pengujian UndangUndang (judicial review), sengketa pemilu (perkara) dan sengketa kewenangan antar lembaga. Todung Mulya Lubis, dalam Rapat Kerja Mahkamah Konstitusi, memuji kiprah Mahkamah Konstitusi selama beberapa tahun berdiri sudah mengeluarkan putusan-putusan milestone. Sementara itu Ketua Mahkamah Konstitusi, Jimly Asshiddiqie, mengatakan bahwa ia berupaya membangun Mahkamah Konstitusi menjadi lembaga modern dan sebagai peradilan yang terpercaya. Kepercayaan itu dibangun antara lain lewat putusan-putusannya. ${ }^{11}$

Berdasarkan daftar rekapitulasi perkara pengujian Undang-Undang yang dilakukan Mahkamah Konstitusi sejak Tahun 2003 sampai dengan tanggal 25 Juni 2008, menunjukkan bahwa dari 149 perkara yang diterima ditambah dengan sisa perkara dari tahun yang lalu, berhasil diselesaikan dan diputuskan sejumlah 140 perkara. Lebih lanjut daftar rekapitulasi tersebut dapat dilihat dalam tabel berikut ini $:^{12}$

\footnotetext{
${ }^{11}$ Lihat situs $\underline{w w w} \cdot$ hukumonline, diakses tanggal 2 Januari 2005

${ }^{12}$ Lihat situs www.mahkamahkonstitusi.go.id.
} 
Tabel 1

Daftar Rekapitulasi Perkara Pengujian Undang-Undang

\begin{tabular}{|c|c|c|c|c|c|c|c|c|c|c|c|c|}
\hline \multirow[b]{2}{*}{ No } & \multirow[b]{2}{*}{ Tahun } & \multirow{2}{*}{$\begin{array}{l}\text { Sisa } \\
\text { Yang } \\
\text { Lalu }\end{array}$} & \multirow[b]{2}{*}{ Diterima } & \multirow{2}{*}{$\begin{array}{c}\text { Jumlah } \\
3+4\end{array}$} & \multicolumn{4}{|c|}{ Putusan } & \multirow{2}{*}{$\begin{array}{c}\text { Jumlah } \\
\text { Putusan } \\
(6+7+8+9=10)\end{array}$} & \multirow{2}{*}{$\begin{array}{l}\text { Sisa } \\
\text { Tahun Ini } \\
(5-10)\end{array}$} & \multirow{2}{*}{$\begin{array}{l}\text { Jumlah } \\
\text { UU Yang } \\
\text { Diuji }\end{array}$} & \multirow{2}{*}{ Keterangan } \\
\hline & & & & & Kabul & Tolak & $\begin{array}{c}\text { Tidak } \\
\text { Diterima }\end{array}$ & $\begin{array}{c}\text { Tarik } \\
\text { Kembali }\end{array}$ & & & & \\
\hline-1 & -2 & -3 & -4 & -5 & -6 & -7 & -8 & -9 & -10 & -11 & -12 & -13 \\
\hline 1 & 2003 & & 24 & 24 & - & - & 3 & 1 & 4 & 20 & 16 & $\begin{array}{l}\text { (8) } 2 \text { tidak } \\
\text { berwenang }\end{array}$ \\
\hline 2 & 2004 & 20 & 27 & 47 & 11 & 8 & 12 & 4 & 35 & 12 & 14 & \\
\hline 3 & 2005 & 12 & 25 & 37 & 10 & 14 & 4 & & 28 & 9 & 12 & \\
\hline 4 & 2006 & 9 & 27 & 36 & 8 & 8 & 11 & 2 & 29 & 7 & 9 & \\
\hline 5 & 2007 & 7 & 30 & 37 & 4 & 11 & 7 & 5 & 27 & 10 & 12 & \\
\hline 6 & 2008 & 10 & 16 & 26 & 4 & 4 & 6 & 3 & 17 & 9 & 6 & \\
\hline & mlah & & 149 & - & 37 & 45 & 43 & 15 & 140 & 9 & 69 & \\
\hline
\end{tabular}

Sementara itu rekapitulasi perkara sengketa kewenangan antar lembaga Negara yang diputus oleh Mahkamah Konstitusi Tahun 2003 sampai dengan tanggal 25 Juni 2008 ada sejumlah 10 putusan. Selengkapnya daftar rekapitulasi perkara tersebut dikemukakan di bawah ini. ${ }^{13}$

Tabel 2

Daftar Rekapitulasi Perkara Sengketa Kewenangan

\begin{tabular}{|c|c|c|c|c|c|c|c|c|c|c|c|}
\hline \multirow[b]{2}{*}{ No } & \multirow[b]{2}{*}{ Tahun } & \multirow{2}{*}{$\begin{array}{l}\text { Sisa } \\
\text { Yang } \\
\text { Lalu }\end{array}$} & \multirow[b]{2}{*}{ Diterima } & \multirow[b]{2}{*}{$\begin{array}{c}\text { Jumlah } \\
3+4\end{array}$} & \multicolumn{4}{|c|}{ Putusan } & \multirow{2}{*}{$\begin{array}{c}\text { Jumlah } \\
\text { Putusan } \\
(6+7+8+9=10)\end{array}$} & \multirow{2}{*}{$\begin{array}{c}\text { Sisa } \\
\text { Tahun Ini } \\
(5-10)\end{array}$} & \multirow{2}{*}{ Keterangan } \\
\hline & & & & & Kabul & Tolak & $\begin{array}{c}\text { Tidak } \\
\text { Diterima }\end{array}$ & $\begin{array}{c}\text { Tarik } \\
\text { Kembali }\end{array}$ & & & \\
\hline-1 & -2 & -3 & -4 & -5 & -6 & -7 & -8 & -9 & -10 & -11 & -13 \\
\hline 1 & 2003 & - & - & - & - & - & - & - & - & - & - \\
\hline 2 & 2004 & - & 1 & 1 & - & 1 & - & - & 1 & 0 & - \\
\hline 3 & 2005 & - & 1 & 1 & - & - & - & - & 0 & 1 & - \\
\hline 4 & 2006 & 1 & 4 & 5 & - & - & 2 & 1 & 3 & 2 & - \\
\hline 5 & 2007 & 2 & 2 & 4 & - & 1 & 1 & - & 2 & 2 & - \\
\hline 6 & 2008 & 2 & 2 & 4 & - & - & 2 & 2 & 4 & 0 & - \\
\hline & mlah & & 10 & - & 0 & 2 & 5 & 3 & 10 & - & \\
\hline
\end{tabular}

Sebagai institusi peradilan yang baru, nampaknya Mahkamah Konstitusi sudah menajalankan tugas dan kewenangannya secara efektif, indikatornya adalah sudah ditanganinya dan diputuskannya perkara-perkara yang diajukan oleh para pemohon. Meskipun demikian, memang harus diakui beberapa putusan Mahkamah Konstitusi masih menimbulkan kontroversial dan belum sepenuhnya dapat dipahami dan diterima oleh masyarakat.

${ }^{13}$ Ibid. 


\section{Beberapa Putusan Penting}

Selama beberapa tahun berdiri, Mahkamah Konstitusi telah membuat beberapa keputusan penting. Beberapa putusan Mahkamah Konstitusi yang dinilai penting selama ini di antaranya adalah $:^{14}$

\section{Pengakuan atas hak pilih eks PKI (Register no. 011-017/PUU-I/2003)}

Setelah berpuluh tahun hak-hak politiknya terkungkung, para eks anggota PKI mulai merasakan angin perubahan. Pada 24 Februari tahun ini, Mahkamah Konstitusi (MK) membacakan putusan yang menyatakan pasal 60 huruf g Undang-Undang No. 12 Tahun 2003 tentang Pemilu tidak mempunyai kekuatan hukum mengikat. Pasal itu memang menghalangi mereka yang selama ini dicap eks-PKI untuk memilih dan dipilih. Meski diwarnai dissenting opinion dari hakim konstitusi Achmad Roestandi, MK mengabulkan permohonan Payung Salenda dan kawan-kawan.

Dalam petitumnya MK memandang ketentuan seperti pasal 60 huruf $\mathrm{g}$ tadi tidak lagi relevan dengan upaya rekonsiliasi nasional. Meskipun keterlibatan PKI dalam peristiwa G30S diyakini banyak kalangan, dan TAP MPRS No. XXY/1966 masih berlaku, bekas anggota PKI harus diperlakukan sama dengan warga negara lainnya tanpa diskriminasi. Putusan ini tak urung menimbulkan pro kontra di tengah masyarakat. Tetapi putusan MK ini telah mengurangi isolasi politik selama puluhan tahun terhadap para eks-PKI.

\section{Gugurnya asas retroaktif untuk tragedi bom Bali (Register No.013/PUU- I/2003)}

Mata dunia sedang tertuju pada proses persidangan para pelaku Bom Bali, ketika tiba-tiba MK membuat suatu putusan kontroversial. Pada 23 Juli 2004, untuk menjawab permohonan judicial review yang diajukan terhukum kasus bom Bali Masykur Abdul Kadir, MK menyatakan pemberlakuan UU No. 16 Tahun 2003 tidak bisa digunakan untuk menjerat para pelaku Bom Bali. Sebab, UU tentang pemberlakuan UU tindak pidana terorisme dalam kasus Bali itu bertentangan dengan Konstitusi. Tetapi di kalangan hakim konstitusi sendiri putusan itu diambil melalui perdebatan sengit dan perbedaan pendapat yang signifikan: lima berbanding empat.

\footnotetext{
${ }^{14}$ Lihat www.hukumonline.com, diakses tanggal 2 Januari 2005
} 
Alasan MK "mencabut nyawa” UU No. 16/2003 tidak lain karena adanya asas retroaktif, pemberlakuan undang-undang untuk suatu peristiwa yang terjadi sebelumnya. Undang-Undang dimaksud adalah UU No. 15/2003 tentang Pemberantasan Tindak Pidana Terorisme. Menurut MK, pemberlakuan asas retroaktif hanya dapat dibenarkan untuk pelanggaran HAM berat.

\section{UU Ketenagalistrikan untuk rakyat (Register No.001, 021-022/PUU-I/ 2003)}

Pemegang otoritas perekonomian seperti kebakaran jenggot mendengar putusan MK terhadap permohonan APHI, Serikat Pekerja PLN dan Ikatan Keluarga Pensiunan Listrik Negara. Dalam putusannya 15 Desember lalu, MK menyatakan Undang-Undang No. 20 Tahun 2002 tentang Ketenagalistrikan tidak berlaku. Undang-Undang ini dinilai menabrak hakekat pasal 33 UUD 1945. Menurut MK, listrik masih merupakan cabang produksi penting dan menguasai hajat hidup orang banyak. Sehingga harus dikuasai oleh negara dan dipergunakan sebesarbesanya untuk kemakmuran rakyat.

Pemohon memang hanya mengajukan permohonan terhadap pasal 16, 17 dan 68. Tetapi karena ketiga pasal itu merupakan jantung dan paradigma Undang-Undang Ketenagalistrikan, maka seluruh materinya dinyatakan tidak mempunyai kekuatan hukum tetap. Ketua MK Jimly Asshiddqie mengatakan bahwa dinamika ekonomi harus tunduk pada hukum. UUD 1945 tidak menolak privatisasi dan liberalisasi.

Hapusnya ancaman pidana bagi orang yang mengaku-ngaku advokat (Register Nomor 006/PUU-II/2004)

Menjelang akhir tahun 2004, tepatnya 13 Desember lalu, MK mengejutkan kalangan advokat dengan mencabut keberlakuan pasal 31 Undang-Undang Advokat. Komite Kerja Advokat Indonesia (KKAI) langsung bereaksi keras dan mengecam putusan itu sebagai penghancur tatanan hukum yang sudah ada. Betapa tidak, pasal ancaman pidana bagi orang-orang yang mengaku advokat itu tak punya kekuatan lagi. Otoritas berwenang tentu akan sulit mengawasi dan menindak orang-orang yang mengaku-ngaku advokat, padahal sebenarnya bukan advokat.

Tetapi hakim MK punya pertimbangan lain. Enam dari sembilan hakim menilai pasal itu dalam praktek dapat melahirkan ketidakpastian hukum dan ketidakadilan bagi masyarakat. Bayangkan, dosen yang 
memberi 'konsultasi' hukum kepada seseorang lalu ia diberi uang terima kasih akan bisa dipidana menurut ketentuan pasal 31. Itu sebabnya pencabutan itu dianggap sebagai angin segar bagi kalangan dosen yang bekerja di LBH-LBH kampus. Permohonan itu sendiri memang diajukan LKPH Universitas Muhammadiyah Malang.

\section{Harga BBM dikendalikan Pemerintah (Register No. 002/PUU-I/2003)}

Pembacaan putusan atas judicial review Undang-Undang No. 22 Tahun 2001 tentang Migas bisa jadi sidang yang paling banyak menyedot perhatian masyarakat. Apalagi, putusan dibacakan dua hari setelah terjadi kenaikan harga BBM Pertamax dan elpiji. Ruang sidang MK penuh, meluber hingga ke tangga di bagian luar. Sementara di depan gedung ratusan hingga ribuan massa berdemo sehingga Jalan Medan Merdeka Barat ditutup kecuali untuk satu jalur. Jalur busway terpaksa dibuka untuk bus reguler.

Tetapi di dalam sidang, hakim telah membacakan sebuah putusan mulus karena disetujui secara bulat kesembilan hakim konstitusi. Meski tidak mengabulkan seluruh permohonan APHI, PBHI, Yayasan 324, SNB dan Serikat Pekerja Karyawan Pertamina itu, MK telah mengembalikan konsep penanganan minyak dan gas bumi ke dalam kerangka pasal 33 UUD 1945.

Selain merevisi sebagian isi pasal 12 ayat (3) dan pasal 22 ayat (1) UU Migas, MK juga mencabut kekuatan mengikat pasal 28 ayat (2) dan ayat (3). Masalahnya, pasal yang disebut terakhir adalah pasal penyerahan penentuan harga BBM kepada mekanisme pasar. MK berpendapat 'campur tangan' pemerintah dalam kebijakan penentuan harga haruslah menjadi kewenangan yang diutamakan untuk cabang produksi yang penting dan menguasai hajat hidup orang banyak'. Toh, Pemerintah masih dapat menentukan harga berdasarkan harga pasar.

\section{Kewenangan Komisi Penyiaran Indonesia dipangkas (Reg. No.05/PUU- I/2003)}

Sebagai pelaksanaan suatu undang-undang, pemerintah akan menerbitkan PP. Kewenangan membuat PP sepenuhnya ada di tangan pemerintah, dalam hal ini presiden dan jajaran pemerintahan. Tetapi Undang-Undang No. 32 Tahun 2002 justru mengikutsertakan Komisi Penyiaran Indonesia (KPI) dalam penyusunan PP. Melalui putusan yang dibacakan 28 Juli, MK mengoreksi 'kesalahan' yang tampak sepele itu. MK menyatakan anak kalimat "KPI bersama..." yang terdapat pada pasal 
62 ayat (1), atau anak kalimat 'atau terjadi sanggahan' pada pasal 44 ayat (1) bertentangan dengan UUD 1945.

Itulah jawaban MK atas permohonan judicial review yang diajukan berbagai organisasi penyiaran dan pertelevisian. Putusan itu bagaimanapun telah memangkas kewenangan KPI. Komisi ini tidak lagi berwenang membuat regulasi tentang Lembaga Penyiaran Publik, kepemilikan silang, peliputan lembaga penyiaran asing, sistem stasiun jaringan, tata cara izin lembaga penyiaran berlangganan, izin menyelenggarakan siaran dan sanksi administratif.

\section{Pijakan hukum boleh dibatalkan, tetapi pemerintahan tetap jalan (Register No. 18/PUU-I/2003)}

Jika suatu peraturan dibatalkan keberlakuannya, mestinya lembaga yang didirikan berdasarkan peraturan tersebut bubar. Tetapi tidak demikian halnya dengan putusan MK tentang pemekaran Papua. Dalam putusannya (11/11), MK menyatakan UU No. 45 Tahun 1999 tidak lagi mempunyai kekuatan hukum tetap. Namun, pembentukan provinsi Irian Jaya Barat dan sejumlah kabupaten yang didasarkan pada UU tersebut tidak ikut dibubarkan. Alasannya, pemerintahan di sana sudah jalan, dan putusan MK baru berlaku sejak mulai dibacakan. Jadi, tidak berlaku surut.

\section{Hapusnya ketidakadilan UU Ketenagakerjaan (Register No. /PUU-I/} 2003)

Di penghujung Oktober 2004, MK mengabulkan sebagian permohonan pengujian UU No. 13 Tahun 2003 tentang Ketenagakerjaan (UUK). MK mencabut pasal 158 dan 159 serta menghapus beberapa bagian anak kalimat pada pasal 160 ayat (1), pasal 170, pasal 171 dan pasal 186. Bahkan dua orang hakim konstitusi, lewat dissenting opinion, meminta lebih banyak pasal yang dikabulkan pengujiannya.

Pasal 158 memberi wewenang kepada pengusaha untuk mem-PHK buruh tanpa melalui pengadilan dan tanpa perlu didukung pengujian alat bukti. Ini berbeda dengan pasal 160 UUK sendiri yang menentukan, buruh yang ditahan polisi bukan atas pengaduan pengusaha masih memperoleh sebagian hak hingga putusan pengadilan ada. Tentu saja secara logika, pengusaha akan memilih cara yang diatur pasal 158 tadi. Celakanya, jika dibawa ke pengadilan, beban pembuktian ada di pundak buruh. Padahal buruh selalu berada di pihak yang lemah. 
Itulah sebabnya MK memandang adanya perlakuan diskriminatif sehingga menyatakan pasal 158 dan 159 tidak mempunyai kekuatan hukum mengikat. Tetapi, dalam putusannya, MK menolak pengujian pasal-pasal mengenai outsourcing.

\section{Pengadilan tak harus berada di bawah MA (Reg No. 004/PUU-II/2004)}

Melalui kebijakan satu atap, mestinya semua lembaga yang menjalankan fungsi pengadilan berada di bawah kendali Mahkamah Agung tanpa kecuali. Anehnya, pengadilan pajak seperti berdiri dengan atap sendiri di bawah kendali Departemen Keuangan. Hal ini dikhawatirkan akan mempengaruhi independensi hakim-hakimnya. Seorang pengusaha, Cornelio Moningka Vega, pun mengajukan judicial review terhadap UU No. 14 Tahun 2002 tentang Pengadilan Pajak. Direktur PT Apota Wibawa Pratama itu menilai UU Pengadilan Pajak bertentangan dengan konsep kekuasaan kehakiman dalam pasal 24 UUD 1945.

Namun dalam putusannya 12 Desember 2004 lalu, MK berpendapat lain. Tidak dikenalnya kasasi dalam pengadilan pajak bukan berarti tidak berpuncak pada MA. Dirjen Pajak Hadi Purnomo mengatakan bahwa MA tetap punya peran di pengadilan pajak meskipun secara organisatoris dan finansial berada di bawah kendali Depkeu. Misalnya mengangkat hakim.

\section{Pupusnya Perjuangan Anggota KPKPN (Register No. 006/PUU-I/2003)}

Akhir Maret lalu, MK membuat putusan penting menolak dan tidak menerima permohonan judicial review Undang-Undang No. 30 Tahun 2002 tentang Komisi Pemberantasan Tindak Pidana Korupsi (KPK) yang diajukan KPKPN dan pribadi-pribadi pengurus Komisi itu. Namun putusan penolakan itu diwarnai beda pendapat dari hakim konstitusi Maruarar Siahaan dan Sudarsono.

Dengan putusan itu, lengkaplah sudah kegagalan perjuangan anggota KPKPN untuk mempertahankan eksistensi Komisi tempat mereka bernaung. Putusan itu semakin mengukuhkan pembubaran Komisi yang mengurusi laporan kekayaan pejabat negara tersebut. Sejatinya, KPKPN melebur ke dalam KPK. Tetapi dalam praktek, semangat transparansi yang ditunjukkan KPKPN belum bisa disamai oleh KPK. Bahkan pada awalnya KPK menolak membuka daftar kekayaan pejabat negara ke publik dengan dalih belum jelas dasar hukumnya. 


\section{Upaya Hukum Terhadap Putusan Tidak Dikenal}

Menurut ketentuan Pasal 47 UU Mahkamah Konstitusi, putusan Mahkamah Konstitusi memperoleh kekuatan hukum tetap sejak selesai diucapkan dalam sidang pleno terbuka untuk umum. Di samping itu UU Mahkamah Konstitusi juga tidak mengatur lembaga upaya hukum bagi pihak-pihak yang merasa keberatan atau tidak puas dengan putusan Mahkamah Konstitusi.

Oleh karena itu sejak putusan diucapkan dalam sidang yang terbuka untuk umum, maka putusan Mahkamah Konstitusi menjadi bersifat final, definitif dan langsung mempunyai akibat hukum. Setelah putusan Mahkamah Konstitusi dijatuhkan, senang atau tidak senang, mau atau tidak mau pihak-pihak yang berperkara harus menerima, karena dalam peraturan perundang-undangan tidak tersedia lagi lembaga upaya hukum bagi pihak-pihak yang merasa tidak puas dengan putusan tersebut.

Dengan demikian putusan Mahkamah Konstitusi bersifat final, mengikat para pihak dan memiliki kekuatan hukum tetap sejak dibacakan, serta tidak berlaku surut (non retro aktif). Hal ini tentunya tidak sesuai kelaziman sebagaimana diatur dalam hukum acara pada umumnya. Dalam hukum acara di lingkungan Peradilan Umum, Peradilan Agama, Peradilan Militer, maupun Peradilan Tata Usaha Negara (PTUN) secara eksplisit diatur adanya mekanisme bagi pihak-pihak yang merasa dirugikan untuk mengajukan keberatan terhadap putusan, melalui pengajuan upaya hukum menurut tata cara yang sudah ditentukan.

Secara filosofis, harus dipahami bahwa Hakim adalah juga manusia biasa yang tidak lepas dari kekeliruan dan kekhilafan. Putusan Hakim bukanlah merupakan putusan Tuhan, sehingga tidak mungkin sempurna. Oleh karena itu, demi keadilan dan kebenaran putusan hakim harus dapat diperbaiki atau dibatalkan jika dalam putusannya terdapat kekhilafan atau kekeliruan. Dalam hal ini, hukum menyediakan sarana atau upaya perbaikan atau pembatalan putusan guna mencegah atau memperbaiki kekhilafan atau kekeliruan putusan. Upaya hukum merupakan hak dari pihak yang berkepentingan, karena itu pula pihak yang bersangkutan sendiri yang harus aktif dengan mengajukannya kepada pengadilan yang diberi kekuasaan untuk itu jika ia menghendakinya. Hakim pun tidak dapat memaksa atau menghalangi pihak-pihak yang akan mempergunakan haknya mengajukan upaya hukum. 
Atas dasar hal-hal di atas, adalah suatu keniscayaan bahwa keberadaan upaya hukum terhadap putusan Mahkamah Konstitusi mestinya dapat dilakukan oleh pencari keadilan. Mengingat hukum acara Mahkamah Konstitusi yang berlaku belum mengakomodir masalah upaya hukum tersebut, perlu kiranya ke depan Undang-Undang No. 24 tahun 2003 tentang Mahkamah Konstitusi dilakukan perubahan-perubahan untuk dapat mewadahi persoalan tersebut. Ini semua dilakukan tidak lain adalah agar hak-hak dan kepentingan pencari keadilan yang merasa dirugikan dalam suatu putusan, dapat menggunakan haknya untuk memperjuangkan kebenaran dan keadilan lebih lanjut. Kepada institusi yang berwenang terutama pihak legislatif dan eksekutif sudah selayaknya mendukung dan menindaklanjuti keinginan politik (political will) dari masyarakat dan pencari keadilan.

\section{Penutup}

Putusan Mahkamah Konstitusi sebagai kelanjutan dari mata rantai mekanisme dan proses pemeriksaan perkara perlu dipahami oleh pencari keadilan. Karena putusan Mahkamah Konstitusi akan berimplikasi terhadap hak-hak dan kepentingannya, yang semestinya sedari awal sudah harus diperhitungkan dengan secermat mungkin. Termasuk dalam hal ini belum diakomodirnya mekanisme upaya hukum terhadap putusan Mahkamah Konstitusi, yang dapat merugikan kepentingan pencari keadilan dalam memperjuangkan hak-hak dan kepentingannya lebih lanjut. Oleh karena itu sudah selayaknya ke depan perlu ada penyempurnaan ketentuan hukum acara Mahkamah Konstitusi, khususnya pengaturan upaya hukum perlu diakomodir dalam perubahan Undang-Undang Mahkamah Konstitusi nantinya.

\section{Daftar Pustaka}

A. Fickar Hadjar, dkk, Pokok-Pokok pikiran dan Rancangan Undang-Undang Mahkamah Konstitusi, KRHN dan Kemitraan, 2003.

Agung Susanto, Hukum Acara Perkara Konstitusi, Mandar Maju, Bandung, 2006.

Ahmad Syahrizal, Peradilan Konstitusi Suatu Studi Tentang Adjudikasi Konstitusional Sebagai Mekanisme Penyelesaian Sengketa Normatif, Pradnya Paramita, Jakarta, 2006. 
Bambang Sutiyoso, Hukum Acara Mahkamah Konstitusi Republik Indonesia, Citra Aditya Bakti, Bandung, 2006.

Fatkhurohman, dkk, Memahami Keberadaan Mahkamah Konstitusi Di Indonesia, Citra Aditya Bakti, Bandung, 2004.

Maruarar Siahaan, Hukum Acara Mahkamah Konstitusi Republik Indonesia, Konstitusi Press, Jakarta, 2005.

Sudikno Mertokusumo, Hukum Acara Perdata Indonesia, Liberty, Yogyakarta, 1998

http://www.hukumonline.com/, beberapa edisi.

http://www.mahkamahkonstitusi.go.id/, beberapa edisi. 